\title{
The Effect of Facebook Activities on Enhancing Oral Communication Skills for EFL Learners
}

\author{
Basmah Issa AlSaleem ${ }^{1}$ \\ ${ }^{1}$ The World Islamic Sciences and Education University, Jordan \\ Correspondence: Basmah Issa AlSaleem, The World Islamic Sciences and Education University, Jordan. E-mail: \\ Dr.basmahalsaleem@gmail.com
}

Received: January 22, 2018

Accepted: February 25, $2018 \quad$ Online Published: April 27, 2018

doi:10.5539/ies.v11n5p144

URL: https://doi.org/10.5539/ies.v11n5p144

\begin{abstract}
This study investigated the effect of utilizing Facebook activities on enhancing oral communication skills for English as Foreign Language learners (EFL) in the English Department at Yarmouk University, Jordan. Participants of the study were first year English Language Bachelor degree students who speak English as a foreign language. The researcher hypothesized that if these learners practiced Facebook activities, their oral communication skills may be improved. For answering questions of the study, the researcher designed a pre-post oral communication skills test to determine the participants' mastery of oral communication skills. Furthermore, she uploaded the activities on a Facebook account that were made available for all the participants of the study. Results revealed that the suggested Facebook activities were effective on improving participants' oral communication skills. Then the study recommended that Facebook activities may be utilizing on improving other skills such as speaking and listening or even English language pronunciation.
\end{abstract}

Keywords: Facebook, activities, oral communication skills, EFL, Jordan

\section{Introduction}

Oral skills are realized as the total responses that were produced by humans in different linguistic contexts; they are also viewed as instruments to reveal what is going learners' minds communicate with others. In addition, they are viewed as strong connectors in the instructional process. Furthermore, this process never stops the oral communication but it helps in thought development and social integration.

The field of English language skills has changed immensely in the term of speaking as it does not restricted in just uttering word and recognizing letters. Additionally, this term has changed to entail various and varied mental processes such as using the correct order to construct words and sentences for speaking, expressing orally about ideas via suitable grammar and cognitive structures. Also, oral express comprehends correct pronunciation, ideas order according to science logic, expressing ideas through suitable vocabulary with correspondence with the rule of choice and synthesis, considering correspondence among meanings and ideas and practicing convenient linguistic form. Similarly, this context has been reflected in the term of teaching speaking, so this important linguistic art and the needed goals are needed to be corresponding with international trends and modern theories paying attention to its education through studies, skills and strategies (Younis, 2001).

Most oral skills require high levels of thought and thinking processes that seized their importance through cognitive productive and complicated processes done in many steps such as inner and outer arousement, organizing mental meanings, converting meanings into signs through choice and synthesizing between them. Also, pronouncing sounds of vocabulary and sentences (Shehata, 2003).

In order to understand learners' oral communication skills in constructing a store of vocabulary and structures, so these vocabulary and structures are needed to be developed in order to grasp meanings of English contexts. Furthermore, regarding the nature of understanding oral communication skills can identified in attracting learners' attention and paving their potentialities for new vocabulary and expressions. So, then, they register these vocabulary and expressions in their own note books. Additionally, utilizing what they have learnt in new contexts and stating linguistic alternatives for different situations (Shehata, 2004).

Through considering the nature of oral communication skills, English language learners who speak other languages should pronounce English letters continuously and separately, use signs, gestures and utilize 
non-linguistic movements to express their ideas, state the correct order for English structure while speaking, differentiate between unusual and ordinary expressions, and use suitable expressions in different and various situations (Shehata, 2004).

When English language learners who speak other languages practice oral communication skills, they do not pronounce the language properly, or even end the message through ideas that was told successfully; they also, form ideas and control words in a weak way (Taema, 2003).

Improving oral communication skills helps those learners speak un hesitated, order speeches in a specific manner, hold perfect control over what they say especially relating to meaning perfection, ideas blindness and mastering the art of speech with its contents such as tuning and versatile voices, press what needed to be pressed and pay attention to exclamations and interrogative parentheses. Considering listeners, they should identify and harmonize with them in speed, slowness, summarization, redundancy and equality. In the same token, having the ability to use convenient pauses, bodily expressive movements and helping aids, attracting and affecting the listener leaving no chance for him to be bored. Thus, this can be done through good data show, outstanding performance, self-confidence and convince in what they say (Al-Naqa, 2003).

Hamdi (2011) mentioned that English language entails four skills; listening, speaking, reading and writing. Continuously, pronouncing words is essentially the origin of two substantial aspects in the English language; sub skills of speaking and listening are essentially the main bases for many skills. In the same manner, AlOmari (2011) depicted that others think that mastering English language is focused on its morphology and grammar without realizing its sounds properly, but the truth is that mastery and proficiency in language cannot be achieved when mastering sounds of language only but it could be accomplished via enhancing oral communication skills because humans communicate orally more than in writing scripts.

Continuously, Taema (1999) referred that oral communication skills, are an end but other skills such as listening, reading, speaking and writing are means that assist learners practicing and expressing the final form of linguistic proficiency. In the same context, Younis (2001) depicted that linguistic aspects are commonly used among other linguistic skills, but oral communication aspects represent $90 \%$ of oral communication as learners need to express ideas, emotions and even attitudes.

Reversely, reasons for significance of oral communication skills are stuck to complexity of modern communicative technologies as they depend on oral interaction such as discussions and debates. So, linguistic expressions are attained to be essential domains not only in enhancing linguistic skills but also in the process of theoretical development in social contexts and areas (Zang \& Alex, 1995).

As for the significance of oral communication skills, they face many various problems that hinder learners from mastering them; continuously these reasons tend to subject choice, non-appropriate use of modern teaching method, too little stated time in teaching them, non-stated bases of assessment, and colloquial usage during teaching and weakness of linguistic outcome. So, the researcher may propose the following question; how can English language learners who speak other languages master oral communication skills? In the same point, many English and foreign studies have such as Abdel-Hamid (1986) and Abualhajaj (1993) assured that oral communication skills need more attention in various stages. 


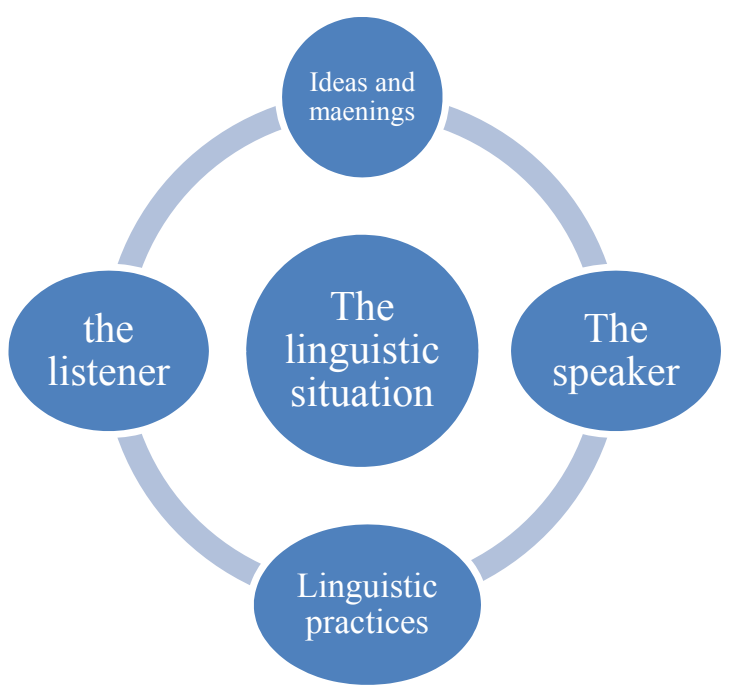

Diagram 1. The linguistic event

Through reviewing this diagram, it is apparent that the linguistic situation entails four components; the speaker, the English Language learner who speak other languages, considering their linguistic differences, diversity of accents and sound in their mother tongues. The listener may be an Arabic speaker, teacher or even the leaners' colleagues. The linguistic practice; means interactions, debates and discussions with English language practioners. Ideas and meanings contain topics and subjects being manipulated in the context of English Language learning.

Concerning the term of learning activities especially their definition, aims and kinds, they are more general and common than electronic activities and they are characterized as one of active learning components. Also, learning activities are realized as the fourth component of curriculum design, as aims state why do learners learn? The content determines; why do students learn? Evaluation; what is the result of learners' education but activities identify how students learn (Shehata, 2003). So, activities can be identified as activities and programs that concern learners and means what theoretical and mind efforts learners practice in correspondence with their attitudes, abilities and concerns inside and outside school. They also, help enrich learners' competency and acquire various experiences to serve their thought and bodily growth (Ibrahim, 1989).

Contextually, the learning activities in the recent study aim at improving learners' skills via e-activities, achieving interaction among learners each other's and between teachers and learners through discussions and dialogues about learners' questions. According to Zaher (2009), e-activities are presented for learners' for raising their abilities in utilizing e-content in attaining communication with students via electronic activities, situations and materials aiming at refreshing adaptation among learners.

Respectfully, the researcher regards e-activities as an electronic communication such as pictures, sounds, diagrams and electronic libraries done through computer screen via electronic educational situations. Abu Ghareeb (2007) added that e-activities depend basically on adopting electronic activities and refreshing students 'senses to work properly with learners' concerns and interests. Also, e-activities are connected to a theoretical theory that depends on learners-centered approach as it helps students to cooperate actively and care immensely between learners in individual differences. Furthermore, Zamel (2013) emphasized that e-activities develop emotional, behavioral and cognitive skills that contribute in utilizing active aids and strategies.

Via social media networks, e-activities are entailed as means for enhancing different and various skills and can be utilized in e-contents for strengthening linguistic communication with others through e-educational situations and other subjects. Some of educational bases for these e-activities are adopting e-activity, sensing, attaching this it to school subjects. Also, focusing on learners concerns and attitudes and attaching it with the cognitive theory that centered about learner as it encourages them for active, effective contribution and differentiates between learners in individual differences (Koper \& Tattersall, 2005).

Furthermore, the e-activities develop cognitive, affective and behavioral skills, utilize active strategies and aids, form suitable experiences about the topic, help learners choose the best alternatives and achieve the demanded of learning and teaching processes. Via the previous contexts, there is a bad need for activities that were uploaded on a Facebook account to contribute in enhancing oral communication skills for English language learners who speak 
other languages. Also, implementing the suitable activities for the contents of lessons, furnishing chances for them to amuse and enjoy through learning and thinking then this leads for more advantages and getting information that may be hard to forget (Faraj, 2013).

Facebook is not always conceptualized similarly to the traditional way of learning. Using Facebook as a personal domain eases communication from peer-to-peer to negotiate academic topics, group discussions and assignments, but they do not often see these practices only as instructions but also as skills enhancement (Bennett, 2011). At best, the place of Facebook practices in language teaching and learning is certain in forming networks of students who create, share, and circulate information and knowledge that may have real impacts on learning (Smith, 2011). Respectively, several studies have yielded that Facebook-integrated lessons, find such lessons effective and appealing (Boyd \& Ellison, 2007) as the students are able to connect with field experts, share links, interact with peers and discover new knowledge; and in some cases perform better than their peers who do not use Facebook academically (Livingstone, 2008).

In the same respect, Palma (2007) asserted that many researches have been carried out to explore their impact on learning in the areas of students' uses of Facebook in higher institutions (Wodzicki, Schwämmlein, \& Moskaliuk, 2012); also, formal and informal learning (Azadeh, 2011); similarly, students and teachers' perceptions of Facebook (Hew, 2011); in the same trend, collaborative learning on Facebook (Toetenel, 2014); in the same context, interaction opportunities (Adi Kasuma \& Wray, 2015); in the same line, relationships between Facebook and academic achievement (Junco, 2012); in the same consensus, critical literacy and language skills (Rambe, 2012); and finally Facebook and second language (L2) learning (Yunus, 2012).

\subsection{Pilot Study}

In the field of oral communication skills, the researcher conducted a pilot study to state practices of English Language learner's level (a sample of twenty learners and identify their problems via practicing oral communication skills after living in An English Language spoken country. Table 1 shows the results of the pilot study:

Table1. Results of pilot study

\begin{tabular}{lccc}
\hline Skill & Available & Unavailable & Percentage \\
\hline Pronounce sounds correctly of their Outs of sounds. & 8 & - & $40 \%$ \\
Differentiate between sounds. & 2 & - & $10 \%$ \\
Reshape the sound according to the situation. & 8 & - & $40 \%$ \\
Express well in different situations. & 4 & - & $20 \%$ \\
\hline
\end{tabular}

Table 1 revealed that most of the English language learners who speak other languages face difficulties in practicing oral communication skills as their percentage in the most higher skill does not precede even $50 \%$. In the same respect, learners face difficulty in oral communication skills via English Language because of the change of pronunciation and also in their mother tongues. So the researcher tried to solve that problem in a context of using Facebook activities with the stated sample.

\subsection{Problem Statement}

Through reviewing the literature, it becomes apparent for the researcher that a great number of researchers dealt with Facebook in tackling many educational problems even with EFL or for Arabic Language learners who speak other languages. Reversely, oral communication skills were utilized via various treatments such as Lafi (1994). In the same respect, Amro (2005) added that there were no basis for evaluating oral communication skills but this can be relied to the opinion of the teachers who practice these skills. So, relying on the results of previous studies, the present study tries to investigate the effect of using Facebook activities in enhancing oral communication skills for English Language learners who speak other languages.

\subsection{Questions}

In order to tackle this problem, the present study attempted to answer the following questions:

What is the effectiveness of using Facebook activities in enhancing oral communication skills for EFL learners in Jordan?

For research purposes this main question can be divided into the following sub-questions:

1) What are the required oral communication skills for EFL learners? 
2) How far do the EFL learners who speak other languages master oral communication skills?

3) What are the features of using Facebook activities to develop oral communication skills of EFL learners?

4) What is the effectiveness of using Facebook activities in enhancing oral communication skills for EFL learners?

\subsection{Purpose}

This study attempted to:

1) Identify the oral communication skills necessary for EFL learners.

2) Assess the current level of EFL learners in the identified oral communication skills.

3) Determine the effectiveness of using Facebook activities in enhancing oral communication skills for EFL learners.

\subsection{Community and Sample}

Few studies have been conducted in the same track in general, and on the oral communication skills in particular. There has also been only limited research in the Arabic context in general, and in the Jordanian context in particular. Therefore, the current research is unique since it examines the impact of Facebook activities to improve oral communication skills for English Language learners who speak other languages. For the purpose of the study, the students at the Centre of Languages at Yarmouk University were chosen as participants of the study.

\subsection{Delimitations}

This study was limited to:

1) A sample of the English Language learners who speak other languages in the Center of Languages at Yarmouk University.

2) Some oral communication skills were utilized for English language learners who speak other languages.

\section{Literature Review}

This portion of the study is dedicated to present related previous empirical studies. For instance;

Graham (2011) in his study mentioned that Facebook is a popular social media website that allows people to interact with friends and loved ones from far away and around the world. With its growing popularity, this study was conducted to examine if Facebook would improve social communication skills of EFL students. A total of nine EFL students on two school campuses participated in the study. A multiple baseline single subject design across settings was used. During the baseline, students were observed and their initiation and reciprocation in communication with peers and teachers were recorded. During the intervention, students were instructed to use Facebook in English language over a two-week period, with appropriate training to assist in improving conversational skills and providing appropriate personal information on the Internet. The results showed that students improved their skills in initiating and reciprocating social communication in English through the use of Facebook, in the meantime, their face-to-face interactions with peers and teachers were increased.

On the other hand, Baruah (2016) claimed that social media like Facebook, twitter, orkut, MySpace, Skype etc., are used extensively for the purpose of communication. One of the most important advantages of the use of social media is the online sharing of knowledge and information among the different groups of people. This online sharing of information also promotes the increase in the communication skills among the people especially among the learners/students of educational institutions. Online tools and technology has not only mediated communication in countless ways, but that the very ways we communicate and even the ways we talk and think about communication are changing as a result. Social media have the potential to fundamentally change the character of our social lives, both on an interpersonal and a community level.

In addition, Toetenel (2014) showed that Facebook is a social media web application used by millions every day. Students use it comfortably and frequently, as a means of genuine communication, mainly for keeping in touch with friends. Actually, we, as young adults, use Facebook as well, some of us extensively, as we acknowledge its excellent role in conveying verbal written messages and visuals. If Facebook is so good in promoting daily communication it should be also profitable in the school environment. Our research, which was developed with a group of students in French and another one in English, consists in creating a Facebook account for a foreign language class where digital "home assignments" are displayed. Our aim is to stimulate more involvement in the learning activity, mainly in the writing assignments. The research that started in the fall 2012 showed that Facebook has indeed a great potential as a means for teachers to reach to their students and experiment with 
learning methods. Students, who had never written their homework before, started responding on Facebook to a variety of communicative assignments. Our conclusion is that since using Facebook the foreign language class has progressed towards an environment of genuine communication.

Teachers and Facebook: using online groups to improve students' communication and engagement in education. Rezende (2016) in his trial to understanding digital tools in education, he reported on how teachers, from different cities in Brazil, used groups on Facebook and how communication between teachers and students was affected by using such groups. This study is framed under the Cultural Historical Activity Theory (CHAT) perspective, and is conceived from a methodological background that invites participants to collaborate during the research. We examined posts from the groups on Facebook from February 2013 to June 2014 by a qualitative approach, together with coding the open-ended qualitative data and comparing their distribution, and analyzed responses to a questionnaire for teachers by the end of the research. Our findings suggest the teachers used the groups for different purposes, which led to an improvement in communication between teachers and students - online and in-classroom - and in students' engagement in the classrooms.

To conclude, social networking is a current phenomenon that consists of both web-based communication with Internet users through websites and interaction with others via cellular phones. The activities of texting and use of the social network site Facebook improved that individuals consider e-interaction effective to communicate and learn languages.

\section{Method}

\subsection{Design}

The study employed the quasi-experimental design in terms of dividing the participants of the study into two groups, an experimental group and a control group. The experimental group was taught using Facebook activities but the control group was taught via the regular method. Table 2 shows the design of the current study.

Table 2. Study design

\begin{tabular}{lccc}
\hline \multirow{2}{*}{ Groups } & \multicolumn{3}{c}{ Main Procedures } \\
\cline { 2 - 4 } & $\begin{array}{c}\text { Pre-test } \\
\text { Pre-Administration }\end{array}$ & Treatment via Facebook & $\begin{array}{c}\text { Post-test } \\
\text { Post-Administration }\end{array}$ \\
\hline Experimental & $\checkmark$ & $\checkmark$ & $\checkmark$ \\
Control & $\checkmark$ & ----- & $\checkmark$ \\
\hline
\end{tabular}

\subsection{Instruments}

The researcher used the following instruments to tackle the problem of the study:

1) An oral communication skills questionnaire to determine the most important required skills for the English Language learners who speak other languages.

2) An observation checklist for the English Language learners who speak other languages designed by the researcher to assess participants' oral practices.

3) An oral communication skills rubric to score the participants' oral communication skills during the pre/post-test.

\subsection{Program}

It was a collection of activities uploaded on Facebook account to develop oral communication skills for the English Language learners who speak other languages.

\subsection{Procedures}

In order to answer the questions of the study, the study proceeded according to the following steps:

- Reviewing the literature and the previous studies related to the features of Facebook activities and oral communication skills for English Language learners who speak other languages.

- Choosing the sample of the study randomly and dividing them into an experimental group and a control group.

- Designing an oral communication skills questionnaire to determine the most required oral communication skills and presenting them to jurors to verify their validity and suitability. 
- Modifying the questionnaire according to the jury's opinions.

- Designing an observation checklist for Arabic Language learners who speak other languages then presenting it to jurors to verify their validity and suitability.

- Modifying the instruments according to the jury's opinions.

- Designing an oral communication skills test and a scoring rubric to assess English Language learners who speak other languages practices.

- Presenting the oral communication skills test and the coring rubric to the jury to verify their validity and suitability.

- Modifying the oral communication skills test and the scoring rubric according to the jury's opinions.

- Applying the aforementioned instruments to determine their reliability.

- Administering the above mentioned instruments as pre administration for both the experimental group and the control group.

- Designing the Facebook activities then presenting them to the jury to identify their suitability for the participants.

- Modifying the program according the jury's opinions in its final form and then applying for the stated participants

- Conducting the program to the experimental group.

- Administering the above mentioned instruments as post administration as a post for both the experimental group and the control group after the program.

- Scoring and treating the data statistically.

- Presenting summary, results, conclusion, and recommendation.

\subsection{Data Analysis}

The researcher used the SPSS statistical package to calculate means, standard deviation of the scores. The " $\mathrm{t}$ " test was used to determine differences between the mean scores of the participants in both groups on the oral communication skills test.

\section{Results and Discussion}

In order to answer the questions of the study, the t-test was used. Results are shown in the following table:

Table 3. T-test of pre-test of oral communication skills comparing the experimental and the control groups

\begin{tabular}{|c|c|c|c|c|c|c|c|}
\hline \multirow{2}{*}{ Oral communication skills } & \multirow{2}{*}{ Groups } & \multirow{2}{*}{$\mathrm{N}$} & \multirow{2}{*}{ Mean } & \multirow{2}{*}{ Std. Deviation } & \multicolumn{3}{|c|}{ T-test for Equality of Means } \\
\hline & & & & & $\mathrm{t}$ & $\mathrm{df}$ & Sig. \\
\hline \multirow{2}{*}{ Conversate with others without previous preparation } & Experimental & 40 & 1.18 & .712 & \multirow{2}{*}{.184} & \multirow{2}{*}{78} & \multirow{2}{*}{ not sig. } \\
\hline & Control & 40 & 1.15 & .483 & & & \\
\hline \multirow{2}{*}{ Inquires his talker out when the meaning is vague } & Experimental & 40 & 1.20 & .911 & \multirow{2}{*}{-.313} & \multirow{2}{*}{78} & \multirow{2}{*}{ not sig. } \\
\hline & Control & 40 & 1.25 & .439 & & & \\
\hline \multirow{2}{*}{ Apparently portrays his points of views } & Experimental & 40 & 1.25 & .954 & \multirow{2}{*}{.000} & \multirow{2}{*}{78} & \multirow{2}{*}{ not sig. } \\
\hline & Control & 40 & 1.25 & .870 & & & \\
\hline \multirow{2}{*}{ Politely comments on others' opinions } & Experimental & 40 & 1.15 & .362 & \multirow{2}{*}{.458} & \multirow{2}{*}{78} & \multirow{2}{*}{ not sig. } \\
\hline & Control & 40 & 1.08 & .971 & & & \\
\hline \multirow{2}{*}{ Co-talks with others autonomously } & Experimental & 40 & 1.13 & .463 & \multirow{2}{*}{.149} & \multirow{2}{*}{78} & \multirow{2}{*}{ not sig. } \\
\hline & Control & 40 & 1.10 & .955 & & & \\
\hline \multirow{2}{*}{ Total } & Experimental & 40 & 5.90 & 1.837 & \multirow{2}{*}{.236} & \multirow{2}{*}{78} & \multirow{2}{*}{ not sig. } \\
\hline & Control & 40 & 5.80 & 1.951 & & & \\
\hline
\end{tabular}

Table 3 reveals that there are no differences between the mean scores of the pre administration of the oral communication skills test and the experimental and the control groups were equivalent. This indicates homogeneity of the two groups. The t-values are between $(-1.0216 \&$.787) and this reflects that there is no statistically significant differences between the mean scores of the experimental and the control groups in the test sub-skills and the total score of the pre-oral communication skills test before conducting the experiment. Thus, any 
variance between the two groups that may happen after the experiment could be attributed the effect of the experiment. The pre-test revealed that most of the students have average proficiency in oral communication test.

Table 4. T-test of the post oral comprehension test comparing the experimental and the control group

\begin{tabular}{|c|c|c|c|c|c|c|c|}
\hline \multirow{2}{*}{ Oral communication skills } & \multirow{2}{*}{ Groups } & \multirow{2}{*}{$\mathrm{N}$} & \multirow{2}{*}{ Mean } & \multirow{2}{*}{ S. Deviation } & \multicolumn{3}{|c|}{ T-test for Equality of Means } \\
\hline & & & & & $\mathrm{t}$ & df & Sig. \\
\hline \multirow{2}{*}{ Conversates with others without previous preparation } & Experimental & 40 & 2.15 & .533 & & & \\
\hline & Control & 40 & 1.48 & .506 & 5.807 & 78 & .05 \\
\hline \multirow{2}{*}{ Inquires his talker out when the meaning is vague } & Experimental & 40 & 2.18 & .636 & & & \\
\hline & Control & 40 & 1.55 & .714 & 4.133 & 78 & .05 \\
\hline \multirow{2}{*}{ Apparently portrays his points of views } & Experimental & 40 & 2.28 & 679 & & & \\
\hline & Control & 40 & 1.60 & .632 & 4.601 & 78 & .05 \\
\hline \multirow{2}{*}{ Politely comments on others' opinions } & Experimental & 40 & 1.85 & .949 & & & \\
\hline & Control & 40 & 1.25 & .494 & 3.549 & 78 & .05 \\
\hline \multirow{2}{*}{ Co-talks with others autonomously } & Experimental & 40 & 1.73 & .987 & & & \\
\hline & Control & 40 & 1.40 & .591 & 1.787 & 78 & .08 \\
\hline \multirow{2}{*}{ Total } & Experimental & 40 & 10.45 & 2.375 & & & \\
\hline & Control & 40 & 7.25 & 1.446 & 7.280 & 78 & .05 \\
\hline
\end{tabular}

Results in Table 4 above shows that the experimental group outperformed the control group in all the oral communication skills post-test. A closer look at Table 4 revealed that (Conversates with others without previous preparation, Inquires his talker out when the meaning is vague, apparently portrays his points of views, Politely comment on others' opinions) was the most improved sub skills (i.e. mean $=2.15,2.18,2.28 \& 1.85$ ). On the other hand, Co-talk with others autonomously; was the least improved skill (mean $=1.73$ ). However, all differences between the experimental and the control group were significant at 0.05 level. This means that the Facebook activities among other variables not measured by this study-was effective in enhancing the students' oral communication skills.

To sum up, the result of this study, which is " there is a statistically significant difference between the mean scores of the experimental group (students who were taught by Facebook activities) and the mean scores of the control group (students who were taught by the regular method) on the overall oral communication skills post test results were in favor of the experimental group, shows the importance of facebook activities on enhancing the EFL communication skills. The current study asserted the importance and impact of using Facebook activities for practicing oral communication skills in classes of English as a foreign language.

Finally, it is obvious that learners can collaborate on team projects for language learning through social media. Learners can co-draft documents, spreadsheets, presentation slides and more with face book. As more systems emerge, there will be greater capacity for groups to organize and participate in collective action and language learning. Thus, one of the foundational concepts in social media is that, with social media, one cannot control one's message completely, but one can contribute to discourses. Social media technologies are capable of reaching audiences all over the world.

\section{Recommendations}

In light of the results of the current study, the researcher suggested applying the Facebook activities to different stages such as primary, secondary and college. In addition, she recommends investigating factors that may affect the students learning on Facebook such as; language proficiency, background knowledge, motivation, perception, age and gender. Also, analyzing the relation between the students' learning style and their preference for learning on Facebook is needed.

\section{References}

Abdel-Hamid, A. (1986). Evaluation of Oral Expression in the Preparatory Stage (Unpublished doctoral message). Faculty of Education, University of Jordan.

Abu Ghareeb, A. (2007). Trends in pre-school child education in some countries of the world. Fifth Annual Scientific Conference, Pre-school Child Education, Reality and Future Aspirations Cairo: The Book Center for Publishing in cooperation with the National Center for Educational Research and Development.

Abuhajjaj, A. (1993). Developing the skills of oral expression and reading in the fifth grade of basic education 
(Unpublished master thesis). Faculty of Education, Beirut University.

Adi Kasuma, S., \& Wray, D. (2015). An informal Facebook group for English language interaction. In 5th Annual International Conference on Education and e-Learning (EeL 2015). Bangkok, Thailand. https://doi.org/10.5176/2251-1814_EeL15.4

Al-Naqa, M., \& Wahid, H. (2004). Teaching English in General Education, Interventions and Techniques (Part One).

Azadeh, S. (2011). Disparities between new media use and critical engagement. Procedia-Social and Behavioral Sciences, 15(0), 761-764.

Bennett, S. (2011). A short history of social media. Mediabistro.com. Retrieved from http://www.mediabistro.com

Boyd, D., \& Ellison, N. (2007). Social network sites: Definition, history, and scholarship. Journal of Computer-Mediated Communication, 13(1). https://doi.org/10.1111/j.1083-6101.2007.00393.x

Drussell, J. (2012). Social Networking and Interpersonal Communication and Conflict Resolution Skills among College Freshmen. Master of Social Work Clinical Research Papers. Retrieved from http://sophia.stkate.edu/msw_papers/21

El Essawy, J. (1991). A program for the development of speaking skills and its impact on the meaningful listening of students of the fourth and fifth grades of basic education (Unpublished doctoral thesis). Faculty of Education, ALalBayt University.

El-Amry, Sh. (2011). Acquisition of listening and speaking skills among non-native speakers of the Arabic language (Unpublished doctorate message). Institute of Research and Educational Studies, Cairo University.

Genna, G. (2012). Using Facebook to improve social communication skills of students. Theses and Dissertations. Retrieved from http://rdw.rowan.edu/etd/205

Hamdy, M. (2011). The Effect of a Proposed Program for Teaching English Sounds Using Multimodal Multimedia in Developing the Skills of Audio Awareness among the Students of the First Class of Education (Unpublished master thesis). Faculty of Education, Yarmouk University.

Hew, K. (2011). Students' and teachers' use of Facebook. Computers in Human Behavior, 27(2), 662-676. https://doi.org/10.1016/j.chb.2010.11.020

Ibrahim, H. (1989). Contemporary Trends in Teaching Living Languages to Speakers of Other Languages. Egypt: Cairo, Dar Al-Fikr.

Irwin, C., Ball, L., Desbrow, B., \& Leveritt, M. (2012). Students' perceptions of using Facebook as an interactive learning resource at university. Australasian Journal of Educational Technology, 28(7), 1221-1232. https://doi.org/10.14742/ajet.798

Issa, A. (2005). Development of the skills of oral expression in the third grade students using the strategies of knowledge (Unpublished master thesis). Faculty of Education, Ain Shams University.

Junco, R. (2012). Too much face and not enough books: The relationship between multiple indices of Facebook use and academic performance. Computers in Human Behavior, 28(1), 187-198. https://doi.org/10.1016/j.chb.2011.08.026

Koper, R., \& Tattersall, C. (2005). Preface to Learning Design: A Handbook on Modelling and Delivering Networked Education and Training. Springer, pp v-xii. https://doi.org/10.5334/2005-18

Krishna, K. (2012). Effectiveness of Social Media as a tool of communication and its potential for technology enabled connections: A micro-level study. International Journal of Scientific and Research Publications, 2.

Lafi, S. (1984). Common Mistakes in the Oral Expression of Basic Education Students, Diagnosis and Treatment Proposals (Unpublished master thesis). Faculty of Education, Arish, Suez Canal University.

Livingstone, S. (2008). Taking risky opportunities in youthful content creation: Teenagers' use of social networking sites for intimacy, privacy and self-expression. New Media and Society, 10(3), 393-411. https://doi.org/10.1177/1461444808089415

Palma, J., Graham, P.. \& Piteira, M. (2007). The e/b-learning: an activity based approach. EUNIS 2007 Conference. Retrieved from http://www.eunis.org/events/congresses/eunis2007/CD/pdf/papers/p93.pdf 
Rambe, P. (2012). Critical discourse analysis of collaborative engagement in Facebook postings. Australasian Journal of Educational Technology, 28(2), 295-314. https://doi.org/10.14742/ajet.875

Rezende, F. (2016). Advancing the study of social media in the communication. Communication Teacher Journal, 30.

Roushdy, T. (1998). The Linguistic Basis of Language Curriculum. Egypt: Cairo, Arab Thought House.

Roushdy, T. (2000). Teaching English in Public Education (Theories and Experiences). Egypt: Cairo, Arab Thought House.

Shehata, H. (2002). Teaching languages between theory and practice.

Shehata, H. (2004). The School Activity: Its Concept, Functions, and Fields of Application. Egypt: Cairo.

Shehata, H., \& Al-Najjar, Z. (2003). Glossary of Educational and Psychological Terms. Egypt: Cairo, Egyptian Lebanese Dar.

Shehata, J., \& Al-Najjar, Z. (2003). Dictionary of Educational and Psychological Terms. Egypt: Cairo, Egyptian Lebanese Dar.

Smith, C. (2011). The 17 most visited sites of 2011 ranked by Google. The Huffington Post. Retrieved from $\mathrm{http}: / / \mathrm{www}$.thehuffingtonpost.com

Toetenel, L. (2014). Social networking: A collaborative open educational resource. Computer Assisted Language Learning, 27(2), 149-162. https://doi.org/10.1080/09588221.2013.818561

Wodzicki, K., Schwämmlein, E., \& Moskaliuk, J. (2012). Actually, I Wanted to Learn: Study-related knowledge exchange on social networking sites. The Internet and Higher Education, 15(1), 9-14. https://doi.org/10.1016/j.iheduc.2011.05.008

Younis, F. (2001). Strategies for teaching Languages. Education Journal, 12, 56-66.

Younis, F., \& Badawi, S. (1983). Teacher's Guide of Teaching English for EFL Students. Arab Organization for Education, Science and Culture Journal, 30, 23-28.

Yunus, M., \& Salehi, H. (2012). The effectiveness of Facebook groups on teaching and improving writing: Students' perceptions. International Journal of Education and Information Technologies, 1(6), 87-96.

Zaher, G. (2009). Electronic Approaches. Cairo: The World of Books.

Zamel, M. (2013). Trends of students of the Faculty of Educational Sciences (UNRWA) towards integrated learning. Journal of the Union of Arab Universities in Amman, 59.

Zhang, H., Alex, H., \& Kortner, N. (1995). Oral language development across the curriculum, K-12. ERIC Digest. ERIC Clearinghouse on Reading English and Communication, Bloomington, IN. ED389029 Speaking Difficulties Encountered by Young EFL Learners. Retrieved from https://www.researchgate.net/publication/270340628_Speaking_Difficulties_Encountered_by_Young_EFL _Learners,on Oct 17th, 2017

\section{Copyrights}

Copyright for this article is retained by the author(s), with first publication rights granted to the journal.

This is an open-access article distributed under the terms and conditions of the Creative Commons Attribution license (http://creativecommons.org/licenses/by/4.0/). 